\title{
Centrapalus pauciflorus: Review of its Medicinal uses, Phytochemistry and Pharmacological Properties
}

\author{
Alfred Maroyi
}

\author{
Department of Botany, University of Fort Hare, Private Bag X1314, Alice 5700, South Africa
}

\begin{abstract}
Centrapalus pauciflorus is a herbaceous plant that is used as a traditional medicine and a source of epoxidised oil. This study is aimed at providing a critical review of the pharmacological properties, phytochemistry and medicinal uses of C. pauciflorus. Documented information on the pharmacological properties, phytochemistry and medicinal uses of $C$. pauciflorus was collected from several online sources, which included Scopus, Google Scholar, PubMed and Science Direct, and pre-electronic sources such as scientific publications, these, books, dissertations, book chapters and journal articles. This study showed that the leaves and epoxidised oil of $C$. pauciflorus are used as traditional medicines for external injury, wounds, diabetes, chest pains, eye infections, stomach problems and skin infections. Phytochemical compounds identified from the species include coumarins, essential oils, fatty acids, flavonol glycosides, phenolic acids, sterols, sesquiterpene lactones, triterpenoids, alkaloids, cardiac glycosides, carotenoids, flavonoids, polyuronoids, saponins, steroids, tannins and terpenoids. Pharmacological research revealed that $C$. pauciflorus extracts and compounds isolated from the species have analgesic, anti-dermatitis, antimicrobial, antiulcerogenic, hypoglycemic, insecticide, larvicidal and sedative activities. Centrapalus pauciflorus should be subjected to detailed phytochemical, pharmacological and toxicological evaluations aimed at correlating its medicinal uses with its phytochemistry and pharmacological activities.
\end{abstract}

Keywords: Asteraceae, Centrapalus pauciflorus, Compositae, ethnopharmacology, herbal medicine, indigenous pharmacopeia, Vernonia galamensis.

\section{INTRODUCTION}

Centrapalus pauciflorus (Willd.) H. Rob. is a herbaceous plant belonging to the Asteraceae or Compositae family. This species was originally treated under the genus Vernonia Schreb., a genus that is now known to be restricted to North America [1]. The genus name Centrapalus Cass. was first proposed in 1817 and remained unused until it was resurrected by Robinson in 1999 [2,3]. The genus Centrapalus consists of nine species, which are mainly annual or perennial herbs, that have been recorded in east, west, central, southern and north Africa [4,5]. Synonyms of C. pauciflorus include Cacalia pauciflora Kuntze, Centrapalus galamensis Cass., Conyza pauciflora Willd., Vernonia afromontana R.E.Fr., V. coelestina Schrad. ex DC., V. filisquama M.G. Gilbert, V. galamensis (Cass.) Less., V. galamensis ssp. afromontana (R.E.Fr.) M.G. Gilbert, V. galamensis var. australis M.G. Gilbert, V. galamensis var. ethiopica M.G. Gilbert, V. galamensis ssp. filisquama (M.G. Gilbert) C. Jeffrey, V. galamensis ssp. galamensis, V. galamensis var. gibbosa (M.G. Gilbert) C. Jeffrey, V. galamensis var. lushotoensis (M.G. Gilbert) C. Jeffrey, V. galamensis ssp. mutomoensis M.G. Gilbert, V. galamensis ssp. nairobensis M.G. Gilbert,

*Address correspondence to this author at the Department of Botany, University of Fort Hare, Private Bag X1314, Alice 5700, South Africa;

Tel/Fax: 0027719600326; E-mail: amaroyi@ufh.ac.za
V. galamensis var. petitiana (A. Rich.) M.G. Gilbert, V. petitiana A. Rich., V. senegalensis Desf. and $V$. zernyi Gilli. [2,3,6]. Centrapalus pauciflorus is an annual or sometimes perennial herb which grows up to 5.0 metres in height [6]. Centrapalus pauciflorus is an erect sometimes straggling, much-branched, with ribbed, finely to coarsely hairy stems. Leaves are sessile, sometimes rather crowded, elliptic or linear to oblanceolate with cuneate or attenuate base and serrated leaf margins. Flowers are usually bisexual, fertile and pink to violet blue in colour. The fruit is a narrowly obovoid achene, with narrow ribs, and dark brown to black in colour. Centrapalus pauciflorus has been recorded in a diverse range of habitats, ranging from disturbed habitats of plains, dry bushland, montane forests, slopes, fallow agricultural and grazing fields, roadsides, eroded lands, ditches, riverbanks to parks at an altitude ranging from $1250 \mathrm{~m}$ to $2500 \mathrm{~m}$ above sea level [7-10]. Centrapalus pauciflorus has been recorded in Benin, Burkina Faso, Cameroon, Cape Verde, Chad, Côte d'Ivoire, Eritrea, Ethiopia, Gambia, Ghana, Guinea-Bissau, Kenya, Liberia, Madagascar, Mali, Mauritania, Niger, Nigeria, Senegal, Sierra Leone, South Sudan, Sudan, Tanzania, Togo and Zimbabwe [3,7,9,11]. Centrapalus pauciflorus is recorded as an arable weed in cereal crops, cotton (Gossypium hirsutum L.), orchards and plantations in Cape Verde, Burkina Faso, Ethiopia, Guinea and Nigeria [8,12]. Centrapalus pauciflorus is also categorized as a weed in Tanzania that is grazed by

() 2020 SET Publisher 
livestock and game [13]. Centrapalus pauciflorus is also categorized as a weed in cowpea (Vigna unguiculata (L.) Walp [14] and corn (Zea mays L.) [15] plots in Nigeria.

Centrapalus pauciflorus seed produces a naturally epoxidised oil characterized by various industrial applications such as in plasticisers, additives in flexible polyvinyl chloride, epoxy resins, adhesives, insecticides and crop-oil concentrates [10,16-19]. Therefore, largescale commercial production of $C$. pauciflorus as a potential new industrial oilseed crop has been started in several countries $[6,10,20]$. A patent was registered about ten years ago, highlighting the use of epoxidised oil, epoxidised wax or epoxidised fatty acid ester isolated from the seeds of $C$. pauciflorus in preparation of a medicament used against various forms of skin diseases [18]. It is, therefore, within this context that the current study was undertaken aimed at documenting the medicinal uses, phytochemistry and pharmacological properties of $C$. pauciflorus.

\section{Medicinal uses}

In Ethiopia, the leaves of $C$. pauciflorus are used as traditional medicines for external injury and wounds [21], while leaf decoction of the species is used against diabetes in Nigeria [22-24] (Table 1). In Kenya, the juice of $C$. pauciflorus is applied topically as a remedy for eye problems [25] and leaf decoction of the species is used as a herbal medicine for stomach problems [20]. In Senegal, the leaves of C. pauciflorus are used as an insecticide, particularly against termites, to protect palisades and timber $[26,27]$. In Tanzania, the leaves of $C$. pauciflorus are used as traditional medicines for chest pains $[20,26,28]$ and stomach problems $[29,30]$ (Table 1).

\section{Nutritional and Phytochemical Composition}

Based on literature records documenting medicinal uses and chemical properties of C. pauciflorus, some researchers have also investigated its nutritional (Table 2) and phytochemical properties (Table 3) aimed at providing an overview of the chemical composition of the species. Characterization of $C$. pauciflorus press cake revealed a wide variety of so-called classic nutrients, such as carbohydrates, proteins, fibres and minerals $[20,31]$ as shown in Table 2, and, therefore, may serve as an animal feed $[17,20,31]$. In Table 2, a reference is also made to the recommended dietary allowance (RDA) representing the average daily intake of essential nutrients that are sufficient to meet the nutrient requirements of a health person. When nutritional composition values of $C$. pauciflorus are compared with RDA values, the species appear to be a good source of calcium, carbohydrates, fibre, magnesium, phosphorus, potassium and proteins (Table 2). The phytochemical compounds that have been identified from the aerial parts, leaves, roots, seeds and seed oil include coumarins, essential oils, fatty acids, flavonol glycosides, phenolic acids, sterols, sesquiterpene lactones and triterpenoids (Table 3 ). Other phytochemical compounds identified from the flowers, leaves and roots of $C$. pauciflorus include alkaloids, cardiac glycosides, carotenoids, flavonoids, polyuronoids, saponins, steroids, tannins and terpenoids [22,32-34]. Some of these phytochemical compounds isolated from the species may be responsible for the biological activities of the species.

\section{Pharmacological Properties}

The following pharmacological activities have been documented from the leaves and roots of $C$. pauciflorus and phytochemical compounds isolated from the species: analgesic, anti-dermatitis, antimicrobial, antiulcerogenic, hypoglycemic, insecticide, larvicidal and sedative activities.

\section{Analgesic Activities}

The leaf and seed extracts of $C$. pauciflorus exhibited analgesic activities against acetic acid

Table 1: Medicinal uses of Centrapalus pauciflorus

\begin{tabular}{|c|c|c|c|}
\hline Medicinal use & Parts used & Country & References \\
\hline \hline Chest pains & Leaves & Nigeria & {$[20,26,28]$} \\
\hline Diabetes & Leaves & Kenya & {$[22-24]$} \\
\hline Eye problems & Leaves & Ethiopia & Senegal \\
\hline External injury and wounds & Leaves & S1] & {$[26,27]$} \\
\hline Insecticide & Leaves & Kenya and Tanzania & {$[20,29,30]$} \\
\hline
\end{tabular}


Table 2: Nutritional Composition of Centrapalus pauciflorus Press Cake

\begin{tabular}{|c|c|c|c|}
\hline Ash (g/100g) & 19.0 & - & [20] \\
\hline Carbohydrate $(\mathrm{g} / 100 \mathrm{~g})$ & 7.0 & 130.0 & [20] \\
\hline Fibre $(g / 100 g)$ & 11.0 & $25.0-38.0$ & [20] \\
\hline Glucose (\%) & 0.8 & - & {$[31]$} \\
\hline Magnesium (mg/g) & 6.9 & $310.0-320.0$ & [31] \\
\hline Phosphorus (mg/g) & 644.0 & 1250.0 & [31] \\
\hline Potassium (mg/g) & 14.2 & 4700.0 & {$[31]$} \\
\hline
\end{tabular}

Table 3: Phytochemical Compounds Identified from Centrapalus pauciflorus

\begin{tabular}{|c|c|c|c|}
\hline Phytochemical compounds & Values & Plant part & Reference \\
\hline \multicolumn{4}{|l|}{ Coumarins } \\
\hline Scopoletin & - & Leaves & [35] \\
\hline \multicolumn{4}{|l|}{ Essential oils } \\
\hline Caryophyllene & - & Aerial parts and roots & {$[36]$} \\
\hline a-humulene & - & Aerial parts and roots & {$[36]$} \\
\hline \multicolumn{4}{|l|}{ Fatty acids } \\
\hline Arachidic acid (\%) & $0.05-0.6$ & Leaves and seeds & {$[8,31,37-39]$} \\
\hline Palmitic acid (\%) & $1.9-22.4$ & Leaves and seeds & {$[8,19,31,37-42]$} \\
\hline Palmitoleic acid (\%) & $0.6-1.7$ & Seeds & {$[8,38]$} \\
\hline Parinaric acid (\%) & $7.7-17.3$ & Leaves and seeds & [38] \\
\hline Stearic acid (\%) & $0.6-3.5$ & Leaves and seeds & {$[8,19,31,37-42]$} \\
\hline Vernolic acid (\%) & $0.02-80.0$ & Leaves and seeds & $\begin{array}{c}{[19,31,36,37,39-} \\
47]\end{array}$ \\
\hline Methyl linoleate (\%) & 11.6 & Seeds & {$[45]$} \\
\hline Methyl vernoleate (\%) & 79.1 & Seeds & {$[45]$} \\
\hline
\end{tabular}


(Table 3). Continued.

\begin{tabular}{|c|c|c|c|}
\hline Phytochemical compounds & Values & Plant part & Reference \\
\hline \multicolumn{4}{|l|}{ Flavonol glycosides } \\
\hline Isorhamnetin 3-O- $\beta$-D-apio-D-furanosyl( $1 \rightarrow 2)-\beta$-D-galactopyranoside & - & Leaves & {$[30]$} \\
\hline Quercetin 3-galactoside & - & Leaves & {$[30]$} \\
\hline Quercetin 3-apiosyl $(1 \rightarrow 2)$ galactoside & - & Leaves & {$[30]$} \\
\hline Quercetin 3-rhamnosyl $(\mid \rightarrow 6)$ galactoside & - & Leaves & {$[30]$} \\
\hline 3-O-methylquercetin & - & Flowers & [33] \\
\hline Kaempferol 3-O- $\alpha$-L-rhamnopyranoside & - & Flowers & [48] \\
\hline Quercetin 3-O-a-L-rhamnopyranoside & - & Flowers & [48] \\
\hline 3-O-methyl quercetin-4'-O- $\beta$-D-glucoside & - & Flowers & {$[48]$} \\
\hline Quercetin & - & Seeds & [49] \\
\hline Quercetin 3-O- $\beta$-D-glucoside & - & Seeds & {$[49]$} \\
\hline Quercetin 3-O- $\beta-D-g a l a c t o s i d e$ & - & Seeds & [49] \\
\hline 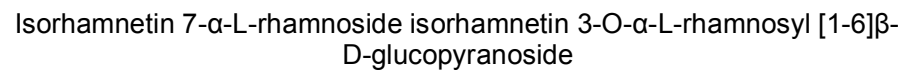 & - & Seeds & {$[49]$} \\
\hline 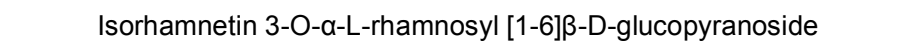 & - & Seeds & [49] \\
\hline Isorhamnetin 3-O- $\beta$-D-apio-furanosyl [1-2]ß-D-galactopyranoside] & - & Seeds & [49] \\
\hline \multicolumn{4}{|l|}{ Phenolic acids } \\
\hline Caffeic acid & - & Leaves & [35] \\
\hline 4-hydroxy-3-methoxy cinnamique acid & - & Leaves & {$[35]$} \\
\hline 3-O-methyl methylgallate & - & Leaves & {$[35]$} \\
\hline 1-(3, 5-dihydroxyphenyl) propene & - & Leaves & [35] \\
\hline \multicolumn{4}{|l|}{ Sesquiterpene lactones } \\
\hline 2a,3a-epoxyprevernocistifolide-8-O-senecioate & - & Aerial parts and roots & [36] \\
\hline 14-O-acetylprevernocistifolide-8-O-senecioate & - & Aerial parts and roots & {$[36]$} \\
\hline 14-O-acetylprevernocistifolide-8-O-isobutyrate & - & $\begin{array}{l}\text { Aerial parts, leaves and } \\
\text { roots }\end{array}$ & {$[36,50]$} \\
\hline Benzylsenecioate & - & Aerial parts and roots & {$[36]$} \\
\hline Glaucogalamensolide isovalerate & - & Aerial parts & {$[51]$} \\
\hline Glaucogalamensolide isobutyrate & - & Aerial parts & {$[51]$} \\
\hline Prevernocistifolide-8-O-isobutyrate & - & $\begin{array}{l}\text { Aerial parts, leaves and } \\
\text { roots }\end{array}$ & {$[36,50]$} \\
\hline Prevernocistifolide-8-O-senecioate & - & $\begin{array}{l}\text { Aerial parts, leaves and } \\
\text { roots }\end{array}$ & {$[36,50]$} \\
\hline Vernolide & - & Leaves & {$[52]$} \\
\hline Vernonioside & - & Leaves & {$[52]$} \\
\hline cis-(12S,13R)-(3-methylpentyl) vernolate & - & Seeds & {$[47]$} \\
\hline cis-(12S,13R)-(2,3-propanediol) vernolate & - & Seeds & {$[47]$} \\
\hline \multicolumn{4}{|l|}{ Sterol } \\
\hline$\Delta^{5}$-avenasterol $(\%)$ & 30.0 & & {$[31]$} \\
\hline 24-methyl cholesta-5-en-3 $\beta$-ol & - & Seed oil & {$[53]$} \\
\hline 24-ethyl cholesta-5,22-dien- $\beta 3$-ol & - & Seed oil & {$[53]$} \\
\hline 24-ethyl cholesta-5-en- $\beta$-ol & - & Seed oil & {$[53]$} \\
\hline 24-ethylidene cholesta-5-en-3ß-ol & - & Seed oil & {$[53]$} \\
\hline 24-ethyl cholesta-7-en- $\beta 3$-ol & - & Seed oil & [53] \\
\hline
\end{tabular}




\begin{tabular}{|c|c|c|c|}
\hline Phytochemical compounds & Values & Plant part & Reference \\
\hline 24-ethylidene cholesta-7-en- $\beta$-ol & - & Seed oil & [53] \\
\hline 24-ethyl cholesta-5-en-3ß-ol (\%) & 36.9 & Seed oil & [53] \\
\hline 24-ethyl cholesta-5,22-diene-3ß-ol (\%) & 18.5 & Seed oil & [53] \\
\hline Cholesta-5-en-3 $\beta$-ol & - & Seed oil & [53] \\
\hline Cholesterol (\%) & 4.6 & & [31] \\
\hline$\beta$-sitosterol (\%) & 32.0 & Aerial parts and roots & {$[31,36]$} \\
\hline Stigmasterol & - & Aerial parts and roots & {$[36]$} \\
\hline Taraxasterol acetate & - & Aerial parts and roots & [36] \\
\hline$\beta$-amyrin & - & Aerial parts and roots & [36] \\
\hline$\beta$-amyrin acetate & - & Aerial parts and roots & [36] \\
\hline Lupeol & - & Aerial parts and roots & [36] \\
\hline Lupeol acetate & - & Aerial parts and roots & {$[36]$} \\
\hline
\end{tabular}

induced writhing in mice at a concentration of 200 $\mathrm{mg} / \mathrm{kg}$ [54].

\section{Anti-Dermatitis Activities}

Epoxidized oil isolated from the seeds of $C$. pauciflorus provide topical medicinal preparations that are effective in the prevention and treatment of various forms of skin diseases, skin lesions and wounds [18].

\section{Antimicrobial Activities}

Mambo et al. [55] evaluated the antimicrobial activities of the vernolamides and vernonia oil isolated from the seeds of $C$. pauciflorus against Staphylococcus aureus, Escherichia coli, Bacillus subtilis, Trichophyton mentagrophyte, Microsporum gypseum, Candida albicans and Saccharomyces cerevisiae using disk diffusion method. The vernolamides exhibited activities against the tested pathogens [55]. Mbugua et al. [56] evaluated the antimicrobial activities of vernonia oil isolated from the seeds of C. pauciflorus against Escherichia coli, Baccilus subtilis and Staphylococcus aureus using the disk diffusion method. The vernonia oil exhibited activities against Escherichia coli and Baccilus subtilis with zone of inhibition of ranging from $7.0 \mathrm{~mm}$ to 17.0 $\mathrm{mm}$ [56]. Tafesse et al. [52] evaluated the antimicrobial activities of acetone extract of the leaves of $C$. pauciflorus and, the compounds vernolide and vernonioside isolated from the species against Staphylococcus aureus ATCC25223, Escherichia coli ATCC23923, Salmonella typhi ATCC13311 and Shigella boydii ATCC9207 using the disk diffusion method with ampicillin, chloramphenicol, ciproflaxin and erythromycin as positive controls. The extract exhibited activities against all tested pathogens with the zone of inhibition ranging from $16.0 \mathrm{~mm}$ to $27.7 \mathrm{~mm}$. The compound vernolide exhibited activities against all the tested pathogens with the exception of Escherichia coli with the zone of inhibition ranging from $17.7 \mathrm{~mm}$ to $18.7 \mathrm{~mm}$. The compound vernonioside exhibited activities against Salmonella typhi and Shigella boydii with the zone of inhibition of $25.7 \mathrm{~mm}$ and $28.7 \mathrm{~mm}$, respectively. The compound vernolide $(0.6 \mathrm{mg} / \mathrm{disc})$ showed activities against all of the tested bacteria except Escherichia coli with minimum inhibitory concentration (MIC) value of $2.5 \mathrm{mg} / \mathrm{mL}$ while vernonioside $(0.48 \mathrm{mg} /$ disk $)$ exhibited activities against Shigella boydii and Salmonella typhi with a MIC value of $1 \mathrm{mg} / \mathrm{mL}$ [52].

\section{Antiulcerogenic Activities}

The leaf and seed extracts of $C$. pauciflorus exhibited antiulcerogenic activities when tested using either hydrochloric acid or ethanol as a necrotising agent in rats [54]. Similarly, Awaad and Grace [49] evaluated the antiulcerogenic activities of the crude 
extracts of $C$. pauciflorus. The pharmacological activity of the extract showed antiulcerogenic activities [49].

\section{Hypoglycemic Activities}

Autamashih et al. [22] evaluated the hypoglycemic activities of aqueous extracts of $C$. pauciflorus leaves on alloxan-induced diabetic male albino rats at the stepping doses of $200 \mathrm{mg} / \mathrm{kg}, 500 \mathrm{mg} / \mathrm{kg}, 700 \mathrm{mg} / \mathrm{kg}$ and $1000 \mathrm{mg} / \mathrm{kg}$ at time intervals of $0,1,3,5$ and 7 hours with metformin $28.6 \mathrm{mg} / \mathrm{kg}$ as the standard antidiabetic drug. A dose of $700 \mathrm{mg} / \mathrm{kg}$ of the crude extract caused the maximum reduction in blood glucose level of $82.7 \%$, which was higher that $73.6 \%$ exhibited by metformin [22].

\section{Insecticide Activities}

Favi and Kraemer [57] evaluated the insecticide activities of volatile oils isolated from the leaves of $C$. pauciflorus against whiteflies and flour beetles. At a concentration of $100.0 \mu \mathrm{L}$ and $200.0 \mu \mathrm{L}$, the extract killed adult whiteflies within an hour and continued to be active for 20 hours. The extract caused mortality of flour beetles fumigated with $3.0 \mathrm{~mL}$ of the extract within 20 hours. However, no mortality was observed when the beetles were under $500.0 \mathrm{~g}$ of flour [57].

\section{Larvicidal Activities}

Tarwish et al. [34] evaluated the larvicidal activities of hexane, chloroform, ethyl acetate, acetone, methanol and water extracts of $C$. pauciflorus leaves and roots against the third instar larvae of malaria vector Anopheles gambiae. All the extracts with the exception of water extracts exhibited activities with acetone extract of the roots exhibiting the median lethal concentration $\left(\mathrm{LC}_{50}\right)$ value of $22.9 \mathrm{ppm}$ [34].

\section{Sedative Activities}

The non-polar fractions of C. pauciflorus leaves exhibited sedative activities at a concentration of 200 $\mathrm{mg} / \mathrm{kg}$ in mice [54].

\section{CONCLUSION}

The present review summarizes the medicinal uses, phytochemistry, and pharmacological properties of $C$. pauciflorus. Detailed studies on the pharmacokinetics, in vivo and clinical research involving both extracts and compounds isolated from the species are required. Therefore, future research should focus on the molecular modes or mechanisms of action, pharmacokinetics and physiological pathways for specific extracts of the species including identification of the bioactive compounds of the species and their associated pharmacological activities.

\section{CONFLICT OF INTEREST}

No conflict of interest is associated with this work.

\section{REFERENCES}

[1] Robinson H, Skvarla JJ, Funk VA. Vernonieae (Asteraceae) of southern Africa: A generic disposition of the species and a study of their pollen. PhytoKeys 2016; 60: 49-126. https://doi.org/10.3897/phytokeys.60.6734

[2] Robinson H. Generic and subtribal classification of American Vernonieae. Smithsonian Contrib Bot 1999; 89: 1-116. https://doi.org/10.5479/si.0081024X.89

[3] Beentje HJ. Compositae (part 1). In Beentje HJ (Ed.), Flora of tropical East Africa. Rotterdam: AA Balkema; 2000, pp. 1313.

[4] Robinson H. Tribe Vernonieae Cass. In Kadereit JW, Jeffrey C (Ed.), The families and genera of vascular plants: Flowering plants: Eudicots, Asterales. Berlin: Springer; 2007 pp. $149-74$

[5] Isawumi MA. The status of generic revision in the African Vernonieae (Asteraceae). Compositae Newslet 2008; 46: 2748.

[6] Ulian $T$, et al. Wild plants for a sustainable future: 110 multipurpose species. Richmond: Royal Botanic Gardens, Kew; 2019.

[7] Jeffrey C. The Vernonieae in East tropical Africa: Notes on Compositae 5. Kew Bull 1988; 43(2): 195-277. https://doi.org/10.2307/4113734

[8] Baye T, Becker HC. Exploration of Vernonia galamensis in Ethiopia, and variation in fatty acid composition of seed oil. Genetic Res Crop Evol 2005; 52: 805-11. https://doi.org/10.1007/s10722-003-6086-5

[9] Beentje H, et al. Asteraceae (Compositae). In Thulin M (Ed.), Flora of Somalia: Volume 3 Angiospermae. Richmond: Royal Botanic Gardens, Kew; 2006, pp. 465-558.

[10] Chakraborty $S$, et al. Exploring the weed biology of two potentially novel oilseed crops: Euphorbia lagascae and Centrapalus pauciflorus. Canadian J PI Sci 2016; 96: 677-88. https://doi.org/10.1139/cjps-2015-0270

[11] Gilbert MG. Notes on East African Vernonieae (Compositae) a revision of the Vernonia galamensis complex: Notes on East African Vernonieae (Compositae) 4. Kew Bull 1986; 41: 19-35.

https://doi.org/10.2307/4103021

[12] Randall RP. A global compendium of weeds. Perth: Western Australia; 2017

[13] Kavana PY, et al. Herbaceous plant species diversity in communal agro-pastoral and conservation areas in western Serengeti, Tanzania. Trop Grasslands 2019; 7(5): 502-18. https://doi.org/10.17138/tgft(7)502-518

[14] Fadayomi O, Olofintoye JA. Weed control in cowpea (Vigna unguiculata (L.) Walp) with imidazolinone herbicide mixtures. J Agr Res Develop 2008; 4: 104-21. https://doi.org/10.4314/jard.v4i2.42175

[15] Chikoye D, Schulz S, Ekeleme F. Evaluation of integrated weed management practices for maize in the northern Guinea savanna of Nigeria. Crop Prot 2004; 23: 895-900. https://doi.org/10.1016/j.cropro.2004.01.013

[16] Bhardwaj HL, et al. Vernonia oilseed production in the midAtlantic region of the United States. Ind Crops Prod 2000; 12 : 119-24.

https://doi.org/10.1016/S0926-6690(00)00046-7 
[17] Baye $\mathrm{T}$, Kebede $\mathrm{H}$, Belete K. Agronomic evaluation of Vernonia galamensis germplasm collected from Eastern Ethiopia. Ind Crops Prod 2001; 14: 179-90. https://doi.org/10.1016/S0926-6690(01)00082-6

[18] McClory PG, Atkinson A. Use of naturally occurring epoxidised molecules from Vernonia galamensis. US Patent no, US7803409 B2; 2010.

[19] Shimelis HA, Mashela PW, Hugo A. Principal agronomic and seed oil traits in the industrial oil crop vernonia (Centrapalus pauciflorus var. ethiopica). S Afr J Plant Soil 2013; 30(3): 131-7.

https://doi.org/10.1080/02571862.2013.843030

[20] Baye TM, Oyen LPA. Vernonia galamensis (Cass.) Less. In Van der Vossen HAM, Mkamilo GS (Eds.), Plant resources of tropical Africa 14: Vegetable oils. Wageningen: Backhuys Publishers; 2007; pp. 178-81.

[21] Teklehaymanot T, Giday M. Quantitative ethnobotany of medicinal plants used by Kara and Kwego semi-pastoralist people in lower Omo River valley, Debub Omo zone, southern nations, nationalities and peoples regional state, Ethiopia. J Ethnopharmacol 2010; 130: 76-84.

https://doi.org/10.1016/j.jep.2010.04.013

[22] Autamashih $M$, Isah $A B$, Allagh TS. Negative intercepts in the Heckel analysis of the crude extract of Vernonia galamensis: A major setback of the equation. J Pharmaceut Negative Res $2011 ; 2: 14-19$

https://doi.org/10.4103/0976-9234.82987

[23] Autamashih $\mathrm{M}$, et al. Heckel and Kawakita analyses of granules of the crude leaves extract of Vernonia galamensis prepared using selected diluents and maize starch mucilage binder. J Current Pharmaceut Review Res 2011; 2(2): 120-9.

[24] Autamashih $M$, et al. Use of hydrophobic fumed silica and selected binders in the tablet formulation of a deliquescent crude plant extract: Vernonia galamensis (Asteraceae). J Pharmaceut Biomed Sci 2011; 6(6): 1-5 https://doi.org/10.4103/0973-8258.82095

[25] Bussmann RW. Ethnobotany of the Samburu of Mt. Nyiru, south Turkana, Kenya. J Ethnobiol Ethnomed 2006; 2: 35. https://doi.org/10.1186/1746-4269-2-35

[26] Burkill HM. The useful plants of west tropical Africa. Richmond: Royal Botanic Gardens Kew; 1985.

[27] Keïta JN, et al. Ethnobotany, phytochemistry and pharmacological profile of Vernonia galamensis (Cass.) Less: A review. Int J Current Adv Res 2017; 6(4): 3187-93. https://doi.org/10.24327/ijcar.2017.3193.0221

[28] Toyang NJ, Verpoorte R. A review of the medicinal potentials of plants of the genus Vernonia (Asteraceae). J Ethnopharmacol 2013; 146: 681-723. https://doi.org/10.1016/j.jep.2013.01.040

[29] Chhabra SC, Mahunnah RLA, Mshiu EN. Plants used in traditional medicine in eastern Tanzania. II angiosperms (Capparidaceae-Ebenaceae). J Ethnopharmacol 1989; 25: 339-9.

https://doi.org/10.1016/0378-8741(89)90038-X

[30] Miserez F, et al. Flavonol glycosides from Vernonia galamensis ssp. nairobiensis. Phytochem 1996; 43(1): 283-6. https://doi.org/10.1016/0031-9422(96)00252-X

[31] Ologunde MO, Ayorinde FO, Shepard RL. Chemical evaluation of defatted Vernonia galamensis meal. J American Oil Chem Soc 1990; 67(2): 92-4. https://doi.org/10.1007/BF02540633

[32] Chhabra SC, Uiso FC, Mshiu EN. Phytochemical screening of Tanzanian medicinal plants. I. J Ethnopharmacol 1984; 11: 157-79. https://doi.org/10.1016/0378-8741(84)90037-0

[33] Doucouré A, et al. Isolation of 3-O-methylquercetin from flowers of Vernonia galamensis (Cass.) Less. Journal Soc Ouest-Afr Chimie 2010; 30: 93-102.
[34] Tarwish B, Ngeranwa JJN, Matasyoh JC. Larvicidal activity and phytochemical composition of crude extracts derived from Vernonia spp. against Anopheles gambiae. Bonorowo Wetlands 2017; 7(2): 108-16.

\section{https://doi.org/10.13057/bonorowo/w070207}

[35] Awaad AS, Sokkar MB, Khafaga HA. Pharmacognostical studies and biological activity for Vernonia galamensis subspecies galamensis var. petitiana (A. Rich) M. Gilbert. Bulletin Faculty Pharm Cairo Univ 2000; 38(3): 107-13.

[36] Perdue RE, Tsichritzis F, Jakupovic J. Prevernocistifolides from Vernonia galamensis. Phytochem 1993; 34(4): 1075-7. https://doi.org/10.1016/S0031-9422(00)90717-9

[37] Ayorinde FO, Butler BD, Clayton MT. Vernonia galamensis: A rich source of epoxy acid. J American Oil Chem Soc 1990; 67: 844-5. https://doi.org/10.1007/BF02540503

[38] Baye T, Becker HC, Witzke-Ehbrecht SV. Vernonia galamensis, a natural source of epoxy oil: Variation in fatty acid composition of seed and leaf lipids. Ind Crops Prod 2005; 21: 257-61.

https://doi.org/10.1016/j.indcrop.2004.04.003

[39] Hadebe S, et al. Seed oil content and fatty acid composition response to ethyl methanesulphonate mutagenesis in Vernonia. S Afr J Plant Soil 2019; 36(5): 375-80. https://doi.org/10.1080/02571862.2019.1631399

[40] Thompson AE, Dierig DA, Kleiman R. Characterization of Vernonia galamensis germplasm for seed oil content, fatty acid composition, seed weight, and chromosome number. Ind Crops Prod 1994; 2(4): 299-305. https://doi.org/10.1016/0926-6690(94)90121-X

[41] Ncube I, et al. Triacylglycerols of Vernonia galamensis seed oil. Phytochem 1998; 47: 723-7. https://doi.org/10.1016/S0031-9422(97)00677-8

[42] Shimelis HA, Labuschagne MT, Hugo A. Variation in oil content and fatty acid composition in selected lines of vernonia (Vernonia galamensis var. ethiopica). S Afr J Plant Soil 2006; 23(1): 62-3. https://doi.org/10.1080/02571862.2006.10634732

[43] Carlson KD, et al. Vernonia galamensis seed oil: A new source for epoxy coatings. In: Pryde EH, Princen LH, Mukherjee KD (Eds.), New sources of fats and oils. Champaign: American Oil Chemists' Society; 1981, pp. 297318.

[44] Perdue RE, Carlson KD, Gilbert MG. Vernonia galamensis, potential new crop source of epoxy acid. Econ Bot 1986; 40(1): 54-68. https://doi.org/10.1007/BF02858947

[45] Billault I, et al. Quantitative deuterium isotopic profiling at natural abundance indicates mechanistic differences for $\delta^{12}$ epoxidase and $\delta^{12}$-desaturase in Vernonia galamensis. J Biol Chem 2005; 280(18): 17645-51. https://doi.org/10.1074/jbc.M500909200

[46] $\mathrm{Yu} \mathrm{K}$, et al. Cloning and functional analysis of two type 1 diacylglycerol acyltransferases from Vernonia galamensis. Phytochem 2008; 69: 1119-27.

https://doi.org/10.1016/j.phytochem.2007.11.015

[47] Fiseha A, et al. Phytochemical investigations of Vernonia galamensis seeds. Chem Nat Compounds 2010; 46(5): 6925. https://doi.org/10.1007/s10600-010-9717-z

[48] Keïta $\mathrm{JN}$, et al. Isolation and identification of three monoglycosylated flavonoids from flowers of Vernonia galamensis ssp. galamensis var. galamensis M. Gilbert. Maghrebian J Pure Appl Sci 2016; 2(2): 39-46.

[49] Awaad AS, Grace MH. Flavonoids and pharmacological activity of Vernonia galamensis ssp. galamensis var. petitiana. Egyptian J Pharmaceut Sci 1999; 40(2): 117-28.

[50] Favi $\mathrm{F}$, et al. Leaf peltate glandular trichomes of Vernonia galamensis ssp. galamensis var. ethiopica Gilbert: 
Development, structure and chemical composition. Int J Plant Sci 2008; 169(5): 605-14.

https://doi.org/10.1086/533598

[51] Zdero C, Bohlmann F, Mungai GM. A glaucolide-type sesquiterpene lactone from Vernonia galamensis ssp. nairobensis. Phytochem 1990; 29(11): 3668-9. https://doi.org/10.1016/0031-9422(90)85300-5

[52] Tafesse G, et al. Antibacterial activity of crude extracts and pure compounds isolated from Vernonia galamensis leaves. Afr J Pharm Pharmacol 2018; 12(11): 136-41. https://doi.org/10.5897/AJPP2018.4888

[53] Artaud J, latrides MC. Sterol composition of Vernonia galamensis seeds. J Fitoterapia 1990; 61(4): 378.

[54] Johri RK, Singh C, Kaul BL. Vernonia lasiopus and Vernonia galamensis: A medicinal perspective. Res Industry 1995; 40: 327-8.
[55] Mambo CK, et al. Synthesis of vernolamides containing tertiary amino groups from Vernonia galamensis oil and their biological activities. Bull Chem Soc Ethiopia 1998; 12(2): 121-8.

https://doi.org/10.4314/bcse.v12i2.21042

[56] Mbugua MN, et al. Conversion of Vernonia galamensis oil to pyridinyl vernolamides and their antimicrobial activities. Bull Chem Soc Ethiopia 2007; 21: 103-10. https://doi.org/10.4314/bcse.v21i1.61384

[57] Favi F, Kraemer M. Agricultural research: Using volatiles from the leaves of Vernonia galamensis to control insect pests. Abstracts of papers, 84th Annual Meeting of the Virginia Academy of Science, Virginia; 2006, pp. 71.

Received on 19-07-2020

Accepted on 09-09-2020

Published on 15-10-2020

DOI: https://doi.org/10.29169/1927-5951.2020.10.05.15

(C) 2020 Alfred Maroyi; Licensee SET Publisher.

This is an open access article licensed under the terms of the Creative Commons Attribution Non-Commercial License (http://creativecommons.org/licenses/by-nc/3.0/) which permits unrestricted, non-commercial use, distribution and reproduction in any medium, provided the work is properly cited. 